Contract No. and Disclaimer:

This manuscript has been authored by Savannah River Nuclear Solutions, LLC under Contract No. DE-AC09-08SR22470 with the U.S. Department of Energy. The United States Government retains and the publisher, by accepting this article for publication, acknowledges that the United States Government retains a non-exclusive, paid-up, irrevocable, worldwide license to publish or reproduce the published form of this work, or allow others to do so, for United States Government purposes. 
SRNS-STI-2011-00085

Proceedings of: PVP2011

2011 Pressure Vessels and Piping Division Conference

July 17 - 21, 2011, Baltimore

PVP2011-57664

\section{Containment Vessel Temperature for Pu-238 Heat Source Container Under Ambient, Free Convection and Low Emissivity Cooling Conditions}

\author{
Allen C. Smith \\ Savannah River National Laboratory \\ Savannah River Nuclear Solutions \\ Aiken, South Carolina 29808 \\ (803) 279 9409, acdocsmith@aol.com
}

\author{
Narendra Gupta \\ Savannah River National Laboratory \\ Savannah River Nuclear Solutions \\ Aiken, South Carolina 29896 \\ (803) 725 5300, nick.gupta@srnl.doe.gov
}

\begin{abstract}
The EP-61 primary containment vessel of the 5320 shipping package has been used for storage and transportation of $\mathrm{Pu}-238$ plutonium oxide heat source material. For storage, the material in its convenience canister called EP-60 is placed in the EP-61 and sealed by two threaded caps with elastomer Oring seals. When the package is shipped, the outer cap is seal welded to the body. While stored, the EP-61s are placed in a cooling water bath. In preparation for welding, several containers are removed from storage and staged to the welding booth. The significant heat generation of the contents, and resulting rapid rise in component temperature necessitates special handling practices. The test described here was performed to determine the temperature rise with time and peak temperature attained for an EP-61 with 203 watts of internal heat generation, upon its removal from the cooling water bath.
\end{abstract}

\section{BACKGROUND}

The 5320 Shipping Package is a dome-topped, upright circular cylinder mounted on a baseplate support by casters. The important details of the 5320 are shown in Figures 1 and 2. In both of these figures, the names of major components are given in capital letters. The maximum weight of the packaging plus payload is $148.3 \mathrm{~kg}(327 \mathrm{lb})$, and nominal height excluding the casters and mounting plates is approximately $82.9 \mathrm{~cm}$ (32.65 in.). Including the casters and mounting plate, the overall height of the 5320 Shipping Package is approximately $95.3 \mathrm{~cm}$ (37.5 in).
The contents of the package (normally handled in the EP-60 product canister) are seal welded into the removable stainless steel primary containment vessel $(\mathrm{PCV})$. The stainless steel secondary containment vessel (SCV) has a removable bolted closure lid. The flange of the SCV has concentric Buna-NTMO -ring and Flexitallic TM gasket seals that satisfy the containment requirements for normal conditions of transport (NCT) and hypothetical accident conditions (HAC), respectively. A finned aluminum shield tank surrounds the nested PCV and SCV. The tank is filled with water extended polyester (WEP) neutron shielding material. The SCV is retained within the inner shell of the shield tank by a bolt that fastens the bottom of the vessel to the baseplate. Heat from the package contents is conducted to the outer shell of the shield tank by radial aluminum webs that connect the inner shell to the outer shell. Axial fins on the outer shell dissipate the heat to the environment. A steel personnel screen encloses the fins and prevents personnel contact during handling operations.

The EP-61 primary containment vessel is used for storage and transportation of $\mathrm{Pu}-238$ plutonium oxide heat source material. It has also been used on occasion for storage and transport of other radioactive materials. Typically, the plutonium oxide material is contained in an EP-60 product canister. For storage, the material in its canister is placed in the EP-61 and sealed by two O-ring seals. When the package is shipped, the cap is seal welded to the body. The space behind the weld (between the weld and the cap O-ring) is charged with helium through a vent hole which is then welded over. The seal weld and the vent hole weld are then helium leak tested. 
The temperature rise during the welding process could result in degradation of the inner (plug) O-ring and outer (cap) O-ring. The heating by the contents increases the peak temperature attained during welding. The EP-61s are stored in a cooling water bath. In preparation for welding, several containers are removed and moved to the welding cell. The temperature of the EP-61s increases with time after they are removed from the cooled storage and placed on the work bench, because only natural convection air cooling is provided. The testing described here investigated temperature rise with time, and the peak temperature attained for an EP-61 with 203 watts of internal heat generation, upon its removal from the cooling water bath.

\section{APPARATUS AND TESTING}

The apparatus for the air cooled heat source test consisted of an instrumented EP-61 assembly, containing an electrically heated EP-60 product container as shown in Figure 3. The EP61 instrumentation consisted of thermocouples and temperature indicating labels and paint dots. Two thermocouples were located at the middle of the payload section of the EP-61, 90 apart. An additional thermocouple was located at the point of transition from the cylindrical body to the end closure. Two thermocouples were installed on the cap, one at the elevation of the O-ring, the other close to the bottom. Temperature indicating dots and labels were located on the body and the cap adjacent to the thermocouples and at the bottom of the body and top of the cap. The arrangement of instrumentation is shown in Figure 4. A hole was drilled in the bottom of the EP-61 body to permit passage of the electrical wires from the heater assembly.

An electrical heater was installed in an EP-60 product container. The heater was coaxial with and axially centered in the EP-60. The axial position was maintained by stainless steel wool packing at each end. The radial gap between the heater and the inside diameter of the EP-60 was filled with steel shot. The EP-60 assembly was placed inside the EP-61, with the electrical wire passing out through the hole in the bottom of the EP-61. The EP-61 plug and cap, with their associated O-rings were then installed.

The apparatus was placed on a well insulated, horizontal surface. The secondary containment vessel EP-61 is placed horizontally as shown in Figure 3. The heater power was adjusted to 203 watts and the assembly was allowed to come to an equilibrium temperature. Power was supplied by a variable transformer power supply. Thermocouple readings were taken every $30 \mathrm{sec}$ by an Omega thermocouple data recorder.

The temperature indicating paints and labels employ materials which change phase (melt) when their characteristic temperature is attained. Upon cooldown, the labels maintain their indication, retaining a glossy, fused appearance, rather than the "flat" appearance of their un-heated condition. If severely overheated, they are blackened. The temperature indicating labels have a series of dots which change color when their characteristic temperature is attained.

The EP-61 as assembled has an overall length of $43.5 \mathrm{~cm}$. The cap diameter is $9.2 \mathrm{~cm}$. The body is $36.8 \mathrm{~cm}$ long and 5.23 $\mathrm{cm}$ in diameter. The container is stainless steel. The outer surface is finished to a surface roughness of 63 micro inches and is then electro-polished. As a result the surface finish is very smooth and bright.

\section{TEST RESULTS}

The results of the Air Cooled Heat Source Test are shown in Figure 3. The apparatus required approximately 3 hours to reach equilibrium. The maximum temperature at the center of the heated section was approximately $288^{\circ} \mathrm{C}\left(550^{\circ} \mathrm{F}\right)$. The temperature at the conical transition was approximately $127^{\circ} \mathrm{C}$ $\left(260^{\circ} \mathrm{F}\right)$, and the temperature of the cap was approximately $93^{\circ} \mathrm{C}\left(200^{\circ} \mathrm{F}\right)$

The heat-up transient shows a distinct lag between the start of heating and the response of the cap thermocouples. This indicates that, if the units are welded promptly, the effect of the internal source on peak O-ring temperature is minimal.

\section{DISCUSSION}

The temperature of the EP-61 at the time of welding is a function of the amount of heat source material it contains and the time elapsed between removal from the cooled storage vault until the weld is performed. The Air Cooled Heat Source Test described here provides an upper bound on the temperatures of an EP-61 loaded with the maximum amount of heat source material allowed by the certificate. The peak temperature at the cap O-ring was found to be $93^{\circ} \mathrm{C}\left(200^{\circ} \mathrm{F}\right)$. The lower thermocouple on the cap is located at the same elevation as the plug O-ring. The surface finish of the threads is good and they are loaded, so that the surface thermal resistance between them is minimized. As a result, the temperature at the plug O-ring must be close to that of the cap at its elevation. An upper bound of $110^{\circ} \mathrm{C}\left(230^{\circ} \mathrm{F}\right)$ is judged to be conservative.

In addition to the absolute temperature measurements, the heat-up and cool-down information was also obtained. Using the temperature rise information, the temperature at the time of welding can be estimated, for a stored EP-61.

The fine surface finish of the EP-61 container is specified to facilitate radiological decontamination. However, it has a significant effect on the heat transfer from the surface and the temperature rise of the container once it is removed from storage. 
The effect of welding on the O-rings is not a concern for containment unless the welding process is interrupted. In this event damage to the O-rings could permit leakage. The effect of welding on temperatures at the O-rings was the subject of a subsequent test. This later test showed that the upper O-rings would withstand the welding operation.

\section{EMISSIVITY OF SURFACE}

The emissivity of the surface was evaluated for the apparatus. It was assumed that $90 \%$ of the heat transfer is through the body section of the EP-61 (i.e., 183w). (The data shows that the temperature gradient at the cap end of the container is low, indicating that most of the heat transfer is from the cylindrical surface of the body. This is similar to neglecting end losses for heat transfer from a long cylinder.) The heat from internal heat generation is transferred by convection and radiation.

$$
\text { Qgenerated }=\text { Qconvection }+ \text { Qradiation }=183 \mathrm{w}
$$

The convection heat transfer coefficient $(h)$ was determined from Incropera ${ }^{[1]}$ for free convection from a horizontal cylinder in ambient air. The $h$ is given by Eq. (1).

$$
\mathrm{h}=\left(\frac{\mathrm{k}}{\mathrm{D}}\right)\left(0.60+\frac{0.387 \times \mathrm{Ra}^{1 / 6}}{\left[1.0+\left(\frac{0.559}{\mathrm{Pr}}\right)^{9 / 16}\right]^{8 / 27}}\right)^{2} \quad \mathrm{Ra}<10^{12}
$$

The air thermal properties are determined at mean boundary layer temperature of air. In Equation (1), Pr is the Prandtl number and the $\mathrm{Ra}$ is the Rayleigh number. $k$ is the air thermal conductivity and $\mathrm{D}$ is the EP-61 diameter. If the $\mathrm{k}$ and $\mathrm{D}$ are in FPS units, $h$ is in Btu/hr- $\mathrm{ft}^{2}-\mathrm{F}$. In the experiment, the surface temperature $\left(\mathrm{T}_{\mathrm{s}}\right)$ was $288^{\circ} \mathrm{C}\left(550^{\circ} \mathrm{F}\right)$ and ambient air $\left(\mathrm{T}_{\text {air }}\right)$ temperature was $24^{\circ} \mathrm{C}\left(75^{\circ} \mathrm{F}\right)$. This gives mean air temperature of $287^{\circ} \mathrm{F}$. The $\operatorname{Pr}$ and the Ra can now be calculated. They are found to be:

$$
\operatorname{Pr}=0.651, \quad \mathrm{Ra}=7.36 \times 10^{5}
$$

The Rayleigh number is less than $10^{7}$ shows that the flow is laminar. For $k=0.0206 \mathrm{Btu} / \mathrm{hr}-\mathrm{ft}-\mathrm{F}$ and $\mathrm{D}=0.1716 \mathrm{ft}(5.23$ $\mathrm{cm}$ ), the Eq. (1) gives $h=1.58 \mathrm{Btu} / \mathrm{hr}-\mathrm{ft}^{2}-\mathrm{F}$. For EP-61 surface area of $606 \mathrm{~cm}^{2}\left(0.6523 \mathrm{ft}^{2}\right)$ and $\Delta \mathrm{T}=475^{\circ} \mathrm{F}$, the heat loss is given by Eq. (2),

$$
\begin{aligned}
\mathrm{Q}_{\text {conv }} & =\mathrm{hA}_{\mathrm{s}}\left(\mathrm{T}_{\mathrm{s}}-\mathrm{T}_{\text {air }}\right) \\
& =489.55 \mathrm{Btu} / \mathrm{hr}=143 \mathrm{w} .
\end{aligned}
$$

The heat transfer due to radiation is the difference between the total heat transfer and that due to convection, i.e., $183-143=$ $40 \mathrm{w}$. For radiation exchange with the surrounding environment, the radiation shape factor, $\mathrm{F}_{\mathrm{se}}$, is 1.0. Assuming no reflection from the surrounding walls, the radiation heat transfer from EP61 is given by Eq. (3):

$$
\begin{aligned}
\mathrm{Q}_{\text {radiation }} & =\mathrm{A}_{\mathrm{s}} \mathrm{F}_{\mathrm{se}} \varepsilon \sigma\left(\mathrm{T}_{\mathrm{s}}^{4}-\mathrm{T}_{\mathrm{e}}^{4}\right) \\
& =40 \mathrm{w}
\end{aligned}
$$

Where:

$$
\begin{aligned}
& \mathrm{A}_{\mathrm{s}}=606 \mathrm{~cm}^{2}=0.0606 \mathrm{~m}^{2} \text { is the surface area } \\
& \mathrm{F}_{\mathrm{se}}=1.0 \text { is the shape factor } \\
& \varepsilon \text { is the emissivity } \\
& \sigma=5.669 \times 10^{-8} \mathrm{w} / \mathrm{m}^{2}-{ }^{-} \mathrm{K} \text { is Stefan-Boltzman constant } \\
& \mathrm{T}_{\mathrm{s}} \text { is the surface temperature, } 561^{\circ} \mathrm{K}\left(288^{\circ} \mathrm{C}\right) \\
& \mathrm{T}_{\mathrm{e}} \text { is the ambient temperature, } 297^{\circ} \mathrm{K}\left(24^{\circ} \mathrm{C}\right)
\end{aligned}
$$

Solving Eq. (3) for $\varepsilon$, we get

$$
\varepsilon=(40 \mathrm{w}) /(314 \mathrm{w})=0.127
$$

The value of emissivity compares closely with typical published values for polished stainless steel of $0.13{ }^{[2]}$

\section{CONCLUSIONS}

The maximum temperature for the body of an air cooled EP61 is approximately $550^{\circ} \mathrm{F}$. The maximum temperature at the O-ring seal is approximately $200^{\circ} \mathrm{F}$. The steady state air cooled temperature bounds the peak temperatures of vessels which are welded promptly.

The peak temperature in the O-ring region, for this bounding case is well within the operational maximum temperature limit for the O-ring material. Consequently, delay in welding will not compromise containment of the contents.

The effect of the internal heat source on the peak temperature experienced during welding is minimal if the welding is performed promptly after removal from the cooled storage sleeve. Even in the event of a delay in welding, the increase in peak temperature compared with a promptly-welded vessel would not affect containment.

\section{CONTRACT NUMBER}

This document was prepared in conjunction with work accomplished under Contract No. DE-AC09-08SR22470 with the U.S. Department of Energy.

\section{DISCLAIMER}

The United States Government retains, and by accepting the article for publication, the publisher acknowledges that the United States Government retains, a non-exclusive, paid-up, 
irrevocable, worldwide license to publish or reproduce the published form of this work, or allow others to do so, for United States Government purposes.

This work was prepared under an agreement with and funded by the U.S. Government. Neither the U. S. Government or its employees, nor any of its contractors, subcontractors or their employees, makes any express or implied: 1 . warranty or assumes any legal liability for the accuracy, completeness, or for the use or results of such use of any information, product, or process disclosed; or 2. representation that such use or results of such use would not infringe privately owned rights; or 3 . endorsement or recommendation of any specifically identified commercial product, process, or service. Any views and opinions of authors expressed in this work do not necessarily state or reflect those of the United States Government, or its contractors, or subcontractors.

\section{REFERENCES}

1. F. P. Incropera and D. P. DeWitt., Fundamentals of Heat and Mass Transfer, 4th Edition, pg. 502, 1996.

2. E. A. Avallone and T. Baumeister III, Marks' Standard Handbook for Mechanical Engineers, $9^{\text {th }}$ Edition, pg. 4-68, 1987.

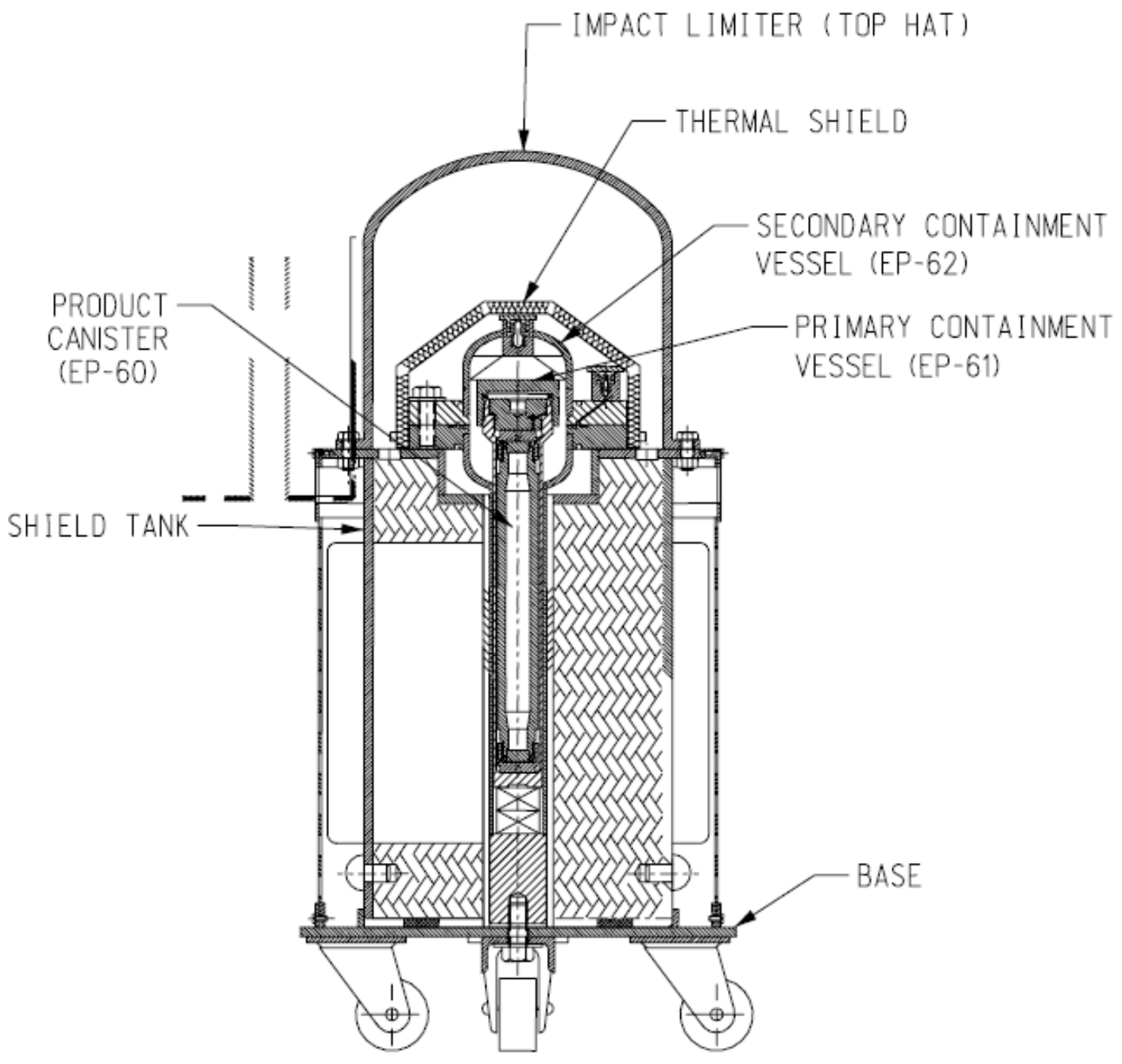

Figure 1. Containment Vessel EP-61 in the 5320 Package 


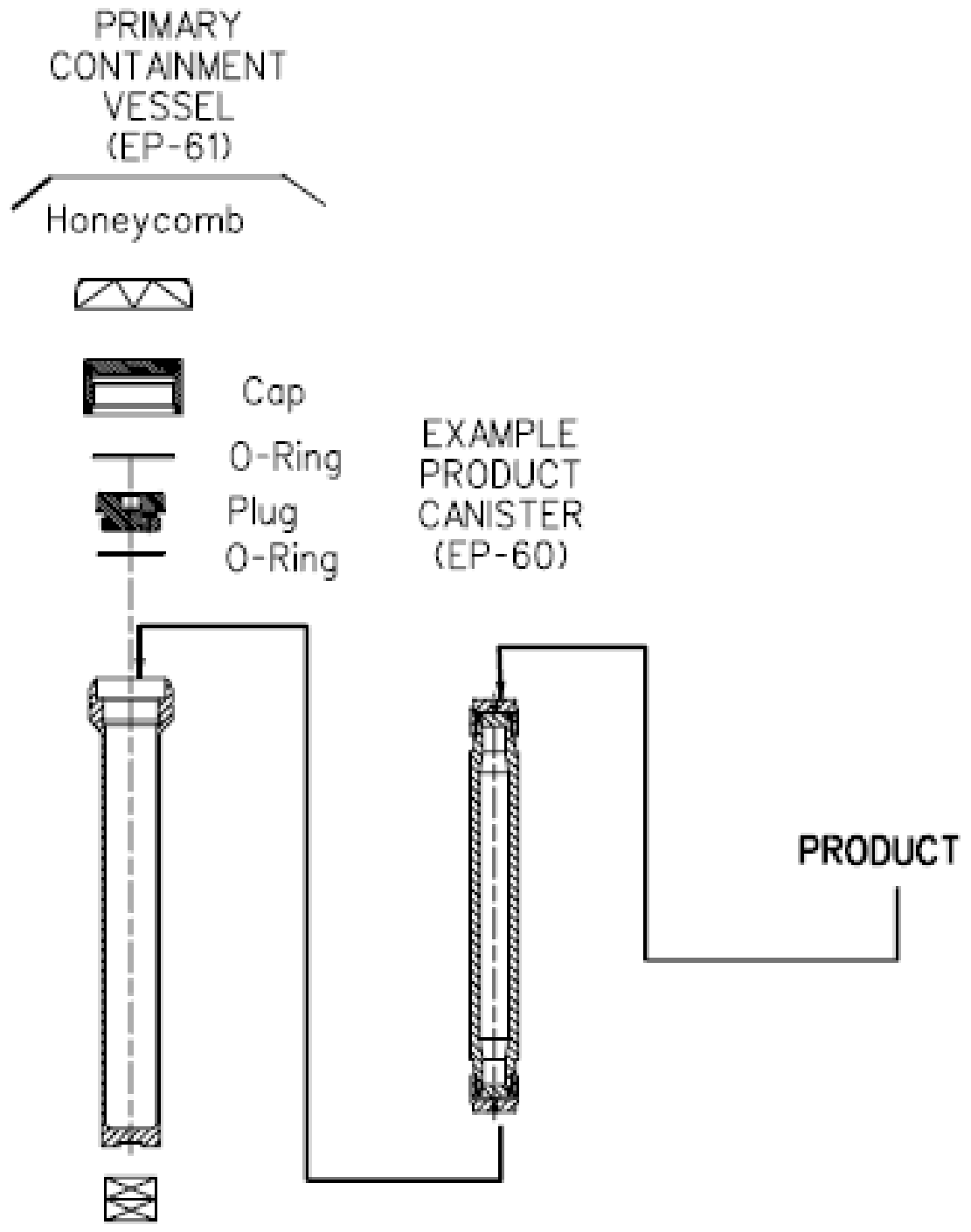

Figure 2. Exploded View of EP-61 and EP-60 


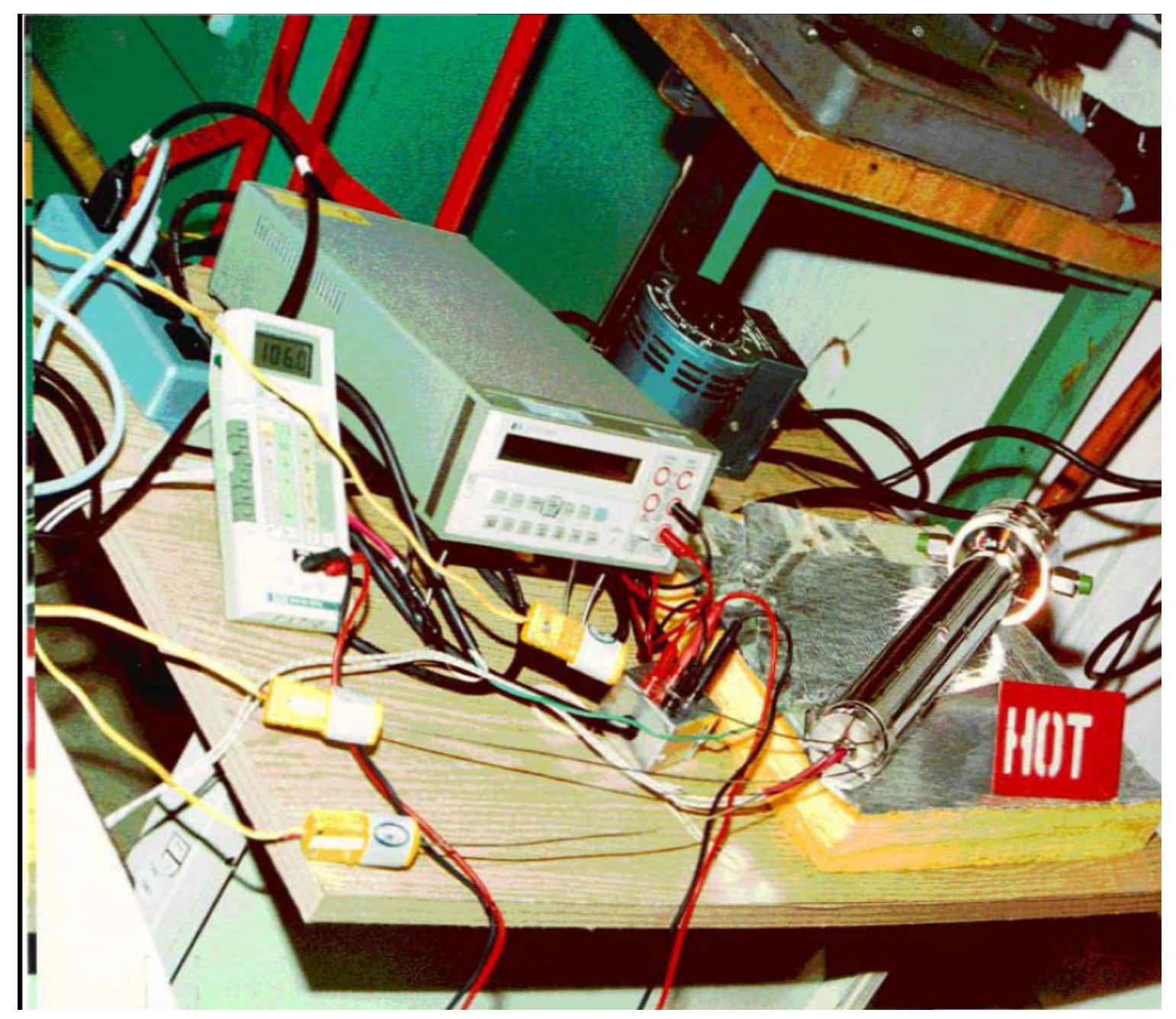

Figure 3. EP-61 test apparatus during the test.

Note: The fine surface finish of the EP-61 container is apparent in this photograph. 


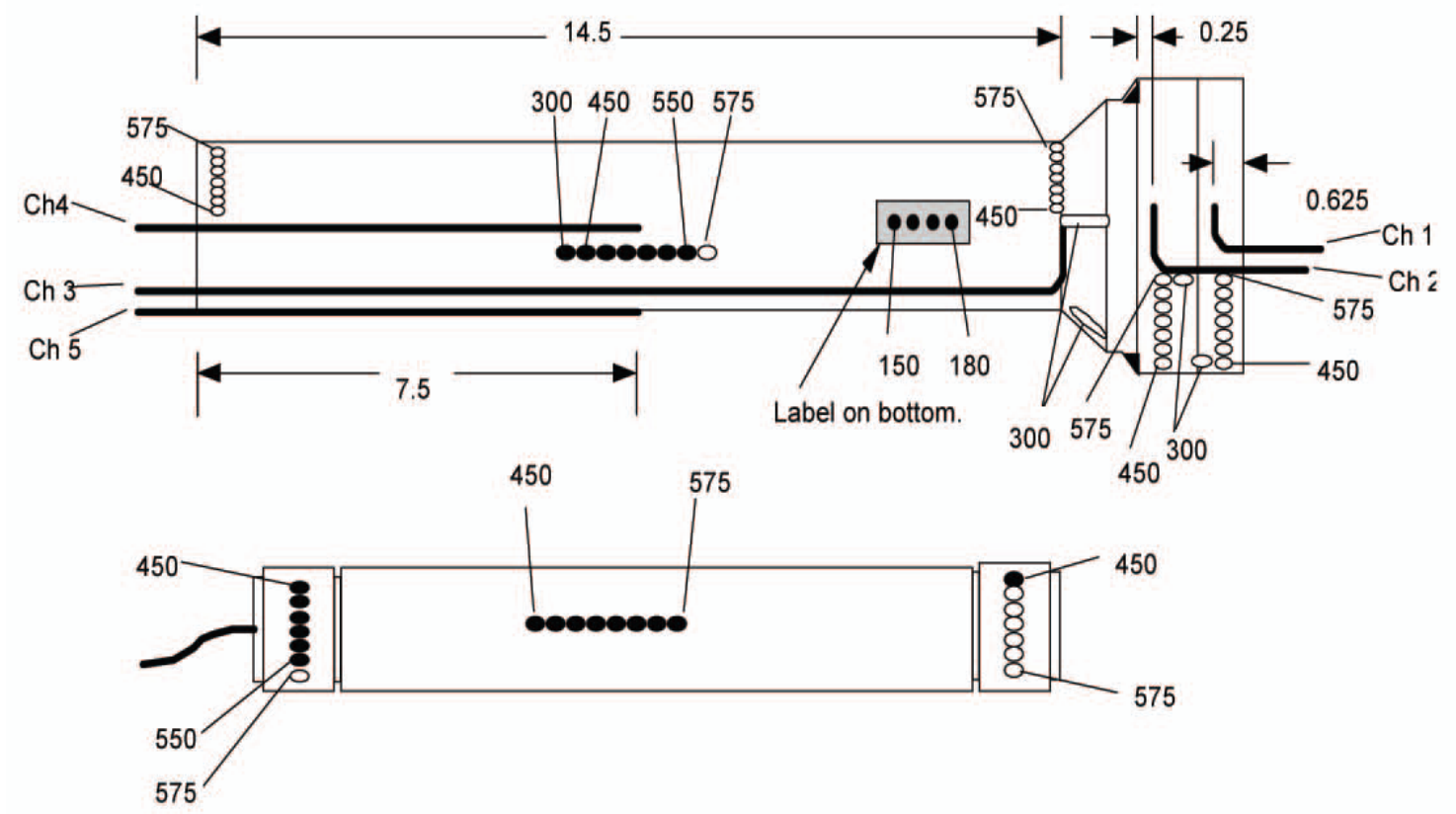

Instrumented EP-61 and EP-60 used for the Air Cooled Maximum Temperature Test. Filled ovals indicate temperature indicating paint dots that were activated during the test.

Figure 4. Thermocouple and Label Locations

\section{EP-61Thermal Test, 203w}

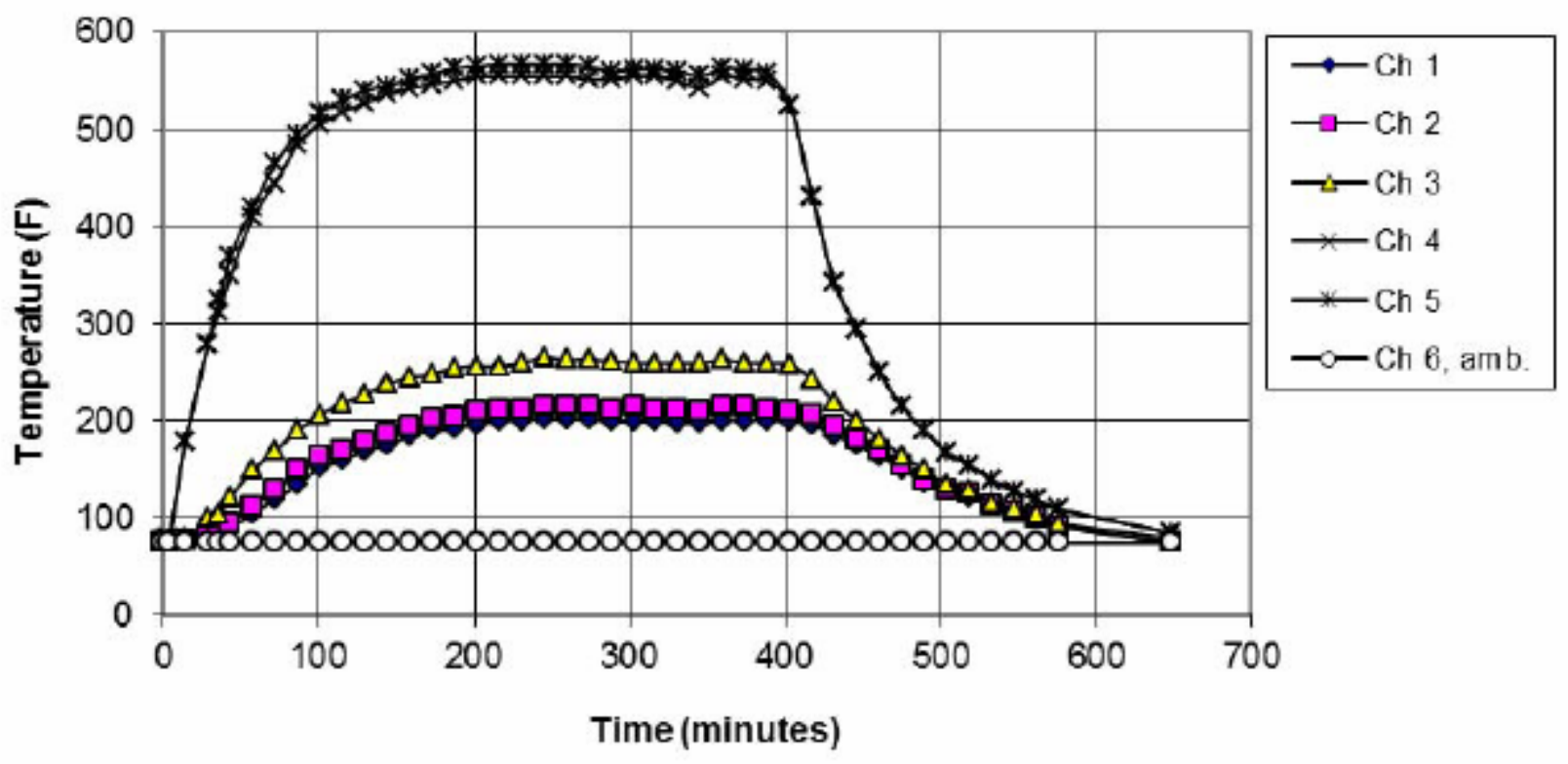

Figure 5. Test Results 